\title{
Cello Pack Dosing Unit
}

National Cancer Institute

\section{Source}

National Cancer Institute. Cello Pack Dosing Unit. NCI Thesaurus. Code C62274.

A dosing unit equal to the amount of active ing redient(s) contained in a cello pack. 